\title{
BRANDING KNOWLEDGE ENHANCEMENT THROUGH ONLINE TRAINING FOR MSMES IN SOUTH JAKARTA
}

\author{
Levyda LEVYDA*, and Titin ASTUTI \\ Sahid University, Indonesia \\ *levyda@usahid.ac.id
}

\begin{abstract}
Brands are essential for consumers and producers, but the number of MSMEs registering their trademarks is limited. MSME knowledge about brands needs to be improved. This community service uses online training attended by 57 participants. Quite several participants have already branded their products, but only a few have registered their brands. They still have difficulty creating a brand and registering it and have financial barriers to registering a brand. The stages of community outreach consist of material preparation, training, discussion, and evaluation stages. From the test results, participants did not understand the brand function for consumers and brand characteristics. Participants' understanding of the function of brands for entrepreneurs and brand elements is quite good. Most participants know that a brand must be registered, but many do not know how to register it. The test results are in line with the discussion; many participants want to know how to make a good brand and the procedure for brand registration. The understanding of the trainees about the improvement brand is quite good. The training concludes that MSMEs still need brand training, especially for online trademark registration procedures. Synchronous online training is practical because participants and trainers can have interactive dialogue so that in the future, online training can continue this activity to enhance MSMEs knowledge.
\end{abstract}

Keywords: Branding Knowledge, Enhancement, Online Training, Online Trademark Registration, MSMEs

\section{BACKGROUND}

Brands are essential for consumers and entrepreneurs, but the awareness of SMEs to register brands is still low. Currently, there are 64.1 million Micro, Small, Medium Enterprises (MSMEs) players in Indonesia, but only 10,632 have already taken care of their trademarks (Caterina, 2021). Therefore, community service is needed to increase their knowledge about the brand.

According to The American Marketing Association (AMA) in (Keller, 2013), a brand is "a name, term, symbol, or design, or a combination of them, intended to identify the goods and services of one seller or group of sellers and to differentiate them from those of competition." Based on the Law on Marks and Geographic Indications of the Republic of Indonesia Number 20 of 2016 (UndangUndang Republik Indonesia Nomor 20 Tahun 2016 Tentang Merek dan Indikasi Geografis (The Law Number 20 Year 2016 on Trademark and Geographical Indications) , a Mark is a sign that can be displayed graphically in the form of an image, logo, name, word, letter, number, colour arrangement in the form of 2 (two) dimensions and/or 3 (three) dimensions. three) dimensions, sound, hologram, or a combination of 2 (two) or more of these elements to distinguish goods and/or services produced by a person or entity law in the activities of trading goods and/or services.

Entrepreneurs especially MSMEs need to register their trademarks because a brand serves as identification to distinguish the resulting yield of a person or persons or legal entity, as a promotional tool, as a guarantee for the quality of goods, and instructions origin of the goods/ services produced. Brand registration serves as evidence for the owner entitled to a registered brand, as a basis for rejection of the same brand in its entirety or the same as the subject matter being applied for to prevent others from using the same brand. The function of the brand for consumers, according to (Keller, 2013), is a source of product identity, a form of assignment of producer responsibility, to reduce risk, reduce search costs, promise, bond or agreement with product manufacturers, as a set of symbols, and quality instructions. For entrepreneurs, the brand serves as a means of identification to simplify handling or tracing, legally protect unique features, signal quality levels to satisfied customers, provide products with individual associations, source of competitive advantage.

There are four steps to managing a brand (Keller, 2013). The first step is to identify and develop a brand plan. The second step is to design and implement a brand marketing program. The third step is measuring and interpreting performance, and the last step is developing brand equity.

Several brand elements can become a brand identity that distinguishes it from other brands, namely brand names, URLs, logos, symbols, characters, spokespeople, slogans, jingles, packages, and jingles (Keller, 2013). Each element should meet the memorable, meaningful, likable, transferable, adaptable, and protectable brand criteria. Brands must be easy to recognize and recall. Brand content must be meaningful, both in the form of descriptive and persuasive content. The band should be rich in imagination, fun, and interesting, even though it is not directly related to the product. Brands must be transferable to new products, which when one day the product develops. Product elements should be able to adapt to the changing environment

The brand name is an important brand element. The brand name serves to identify the product, reflect several symbols and meanings, and become an attraction for consumers. Branding naming processing is described as follows (Kohli \& Labahn, 1997) (Kohli \& Labahn, 1997) 


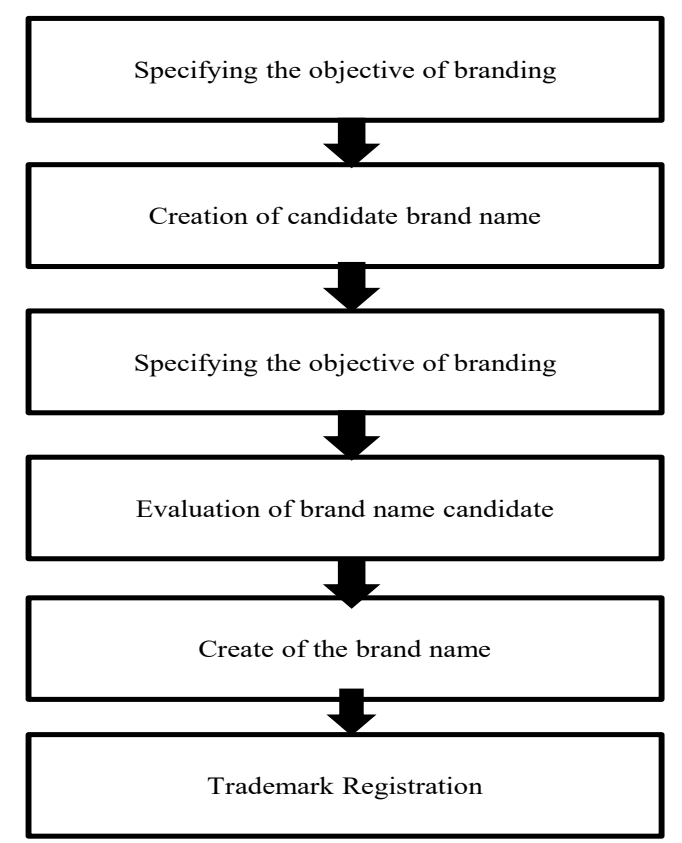

Figure 1. Brand Naming Process

\section{METHODS}

The training was held on March 26, 2021, attended by 57 participants. The description of the trainees is as follows.

Most of the participants were women. The age of the participants varied widely, but most of them were over 40 years old. The education of the participants also varied, but most of them had high school education. Most of the

Table 1 Characteristics of Training Participants participants are in the culinary business, the second-most in the fashion business. The income of the participants is also quite diverse, but most of them earn Rp. 1,000,000 to Rp. 3,999,999 and Rp. 4,000,000 to Rp. 6,999,999.

The training is held online. Online training is a form of training delivered using the internet. The advantage of online training for trainers and trainees is that it is simpler, easier, and more effective. The training is delivered using a laptop or smartphone (Akhter et al., 2021). The training is carried out synchronously so that the trainer and participants can interact directly. It is advisable to use simple text and graphics or images.

The stages of Community Service consist of material preparation and quizzes, material presentation, brand element simulation from examples, Discussion and Questions and Answers, and Quiz. The material presented consists of the Role of a brand, Brand function for customers and entrepreneurs, Brand elements, Brand criteria, and Brand registration.

Participants are asked to assess brand identity based on brand criteria. Steps to assess brand identity are: participants are asked to name their brand, selected a brand to be assessed, participants are invited to assess the brand using the brand criteria using some questions. The questions to guide participants in evaluating the brand are: 1. Is the brand "Bunda" easy to remember and recall?

2. Does the brand "Bunda" have any meaning? For example, everyone will have a deep impression with the word "Bunda"

\begin{tabular}{|c|c|c|c|}
\hline Characteristics of participants & & Total Number & Percentage \\
\hline \multicolumn{4}{|l|}{ Gender: } \\
\hline Male & 19 & $33.33 \%$ & \\
\hline Female & 38 & $66.67 \%$ & \\
\hline \multicolumn{4}{|l|}{ Age: } \\
\hline Less than 25 years old & 2 & $3.51 \%$ & \\
\hline $25-29$ years old & 6 & $10.53 \%$ & \\
\hline $30-34$ years old & 4 & $7.02 \%$ & \\
\hline 35 - 39 years old & 5 & $8.77 \%$ & \\
\hline $40-44$ years old & 14 & $24.56 \%$ & \\
\hline $45-50$ years & 12 & $21.05 \%$ & \\
\hline More than 50 years & 14 & $24.56 \%$ & \\
\hline \multicolumn{4}{|l|}{ Education } \\
\hline Primary school & 4 & $7.02 \%$ & \\
\hline Junior high school & 2 & $3.51 \%$ & \\
\hline Senior High School & 33 & $57.89 \%$ & \\
\hline Non Degree & 5 & $8.77 \%$ & \\
\hline Bachelor & 12 & $21.05 \%$ & \\
\hline Master & 1 & $1.75 \%$ & \\
\hline \multicolumn{4}{|l|}{ Type of business } \\
\hline Fashion & 6 & $10.53 \%$ & \\
\hline Service & 4 & $7.02 \%$ & \\
\hline Culinary & 39 & $68.42 \%$ & \\
\hline Pulse & 1 & $1.75 \%$ & \\
\hline Others & 7 & $12.28 \%$ & \\
\hline \multicolumn{4}{|l|}{ Income per month } \\
\hline$\leq$ Rp. 1.000 .000 & 11 & $19.30 \%$ & \\
\hline Rp. 1.000 .000 - Rp. 3.999 .999 & 21 & $36.84 \%$ & \\
\hline Rp. 4.000 .000 - Rp. 6.999 .999 & 14 & $24.56 \%$ & \\
\hline Rp. 7.000 .000 - Rp. 9.999 .9 & 2 & $3.51 \%$ & \\
\hline$\geq$ Rp. 10.000 .000 & 9 & $15.79 \%$ & \\
\hline
\end{tabular}


3. Is the brand "Bunda" liked by everyone? Does the brand "Bunda" evoke the imagination of consumers

4. If there are additional products, can the "Bunda "can be used?

5. Can the "Bunda" be expanded?

6. Can the "Bunda" be registered?

The last step of this training is to measure the results of the training by giving quizzes. Quiz is delivered online. The quiz consists of five questions and is in the form of multiple choice. Each question represents discussion material.

\section{RESULT AND DISCUSSION}

$52.63 \%$ of the trainees already have their brand of goods/services, but only $8.77 \%$ have registered their brand only. From the discussion, the participants realized the benefits of brands for their business and consumers, but branding is finding product names and creating logos/ symbols. They did not register the mark because $35.8 \%$ did not know how to register and $38.6 \%$ due to lack of money. Brand registration can be done online and offline. Overall, participants' responses to the brand are as follows.

\section{Table 2 Participant Branding Description}

\begin{tabular}{lll}
\hline Characteristics of Participants & Total Participants & Percentage \\
\hline Brand ownership & 30 & $52.63 \%$ \\
Yes & 27 & $47.37 \%$ \\
No & & \\
Registered Brand & 5 & $8.77 \%$ \\
Yes & 52 & $91.23 \%$ \\
No & & \\
Difficulty in creating a brand & 21 & $36.84 \%$ \\
Difficulty making logos/ & 8 & $14.04 \%$ \\
symbols & 28 & $49.12 \%$ \\
Having trouble finding the right & \\
name & & \\
Other & & \\
Reasons for not registering the & & \\
brand & 20 & $35.09 \%$ \\
$\begin{array}{l}\text { Don't know how to register a } \\
\text { brand }\end{array}$ & 22 & $26.32 \%$ \\
No funds & 15 & \\
Other & & \\
\hline
\end{tabular}

The participants did not all understand the role of the brand for entrepreneurs. Participants who answered the role of the brand correctly for entrepreneurs were quite a lot, $61.40 \%$, and the remaining $57.89 \%$ answered incorrectly. Training participants who responded correctly to questions about the role of brands for entrepreneurs were still low at $42.11 \%$, while those who answered incorrectly were still high at $57.89 \%$. Participants' understanding of brand elements is quite good. Many participants gave correct answers to questions about brand elements, namely 68.42\%. However, participants' knowledge of brand characteristics is still low. Participants who gave correct answers to questions about brand characteristics were $40.35 \%$. Most of the participants understand the brands that can be registered, which is $85.96 \%$. Only a few participants did not understand the brands that could be registered. One of the advantages of a brand is that it is transferable. Only $50.88 \%$ of participants answered correctly that the brand could be transferred. Brand elements vary. Still, few realize that color and URL are also brand elements. Only 50.88\% answer the question correctly. Based on their dimensions, brands can be grouped into three-dimensional and two-dimensional brands. Most of the participants answered correctly that a hologram is a three-dimensional brand, but there are still many who have not been able to identify the type of twodimensional brand.

\section{Table 3. Quiz Score}

\begin{tabular}{lll}
\hline \multicolumn{1}{c}{ Questions } & $\begin{array}{r}\text { Correct } \\
\text { answer }\end{array}$ & $\begin{array}{r}\text { Wrong } \\
\text { answer }\end{array}$ \\
\hline Brand function for entrepreneurs & $61.40 \%$ & $38.60 \%$ \\
Brand function for consumers & $42.11 \%$ & $57.89 \%$ \\
Brand elements & $68.42 \%$ & $31.58 \%$ \\
Brand characteristics & $40.35 \%$ & $59.65 \%$ \\
Obligation to register a brand & $85.96 \%$ & $14.04 \%$ \\
Brand elements & $50.88 \%$ & $49.12 \%$ \\
Brand registration function & $73.68 \%$ & $26.32 \%$ \\
Three-dimensional brand & $70.18 \%$ & $29.82 \%$ \\
Two-dimensional brand & $49.12 \%$ & $50.88 \%$ \\
\hline
\end{tabular}

During the training activities, there were several questions from the participants. The questions are classified based on the subtopics of the material as follows.

Table 4. Classification of Participant Questions

\begin{tabular}{|c|c|}
\hline Questions & Type of question \\
\hline $\begin{array}{l}\text { 1. How long does the registration } \\
\text { process take, what are the } \\
\text { requirements }\end{array}$ & Brand registration \\
\hline $\begin{array}{l}\text { 2. Can coffee farmers in other } \\
\text { areas have their brands } \\
\text { registered in Jakarta? }\end{array}$ & Brand registration \\
\hline $\begin{array}{l}\text { 3. Is it possible to register the } \\
\text { "Bunda" brand for sticky rice } \\
\text { chips? }\end{array}$ & $\begin{array}{l}\text { Brand element, brand } \\
\text { registration }\end{array}$ \\
\hline $\begin{array}{l}\text { 4. Is it possible to register a } \\
\text { trademark for forest honey? }\end{array}$ & $\begin{array}{l}\text { Brand element \& brand } \\
\text { registration }\end{array}$ \\
\hline $\begin{array}{l}\text { 5. Can brand for spaghetti use } \\
\text { names/terms in Indonesian? }\end{array}$ & $\begin{array}{l}\text { Brand element \& brand } \\
\text { registration }\end{array}$ \\
\hline $\begin{array}{l}\text { 6. Can computer repair services } \\
\text { register their trademark? }\end{array}$ & $\begin{array}{l}\text { Brand element \& brand } \\
\text { registration }\end{array}$ \\
\hline 7. Can the brand be in English? & $\begin{array}{l}\text { Brand element \& brand } \\
\text { registration }\end{array}$ \\
\hline $\begin{array}{l}\text { 8. Can one brand be used for } \\
\text { several types of confectionery } \\
\text { products? }\end{array}$ & $\begin{array}{l}\text { Brand element \& brand } \\
\text { registration }\end{array}$ \\
\hline
\end{tabular}

Based on the participants' questions, most needed to get input about the branding process. Branding must be simulated as described in Figure 1 to get a brand that fits the brand criteria. The second most common question is brand registration. Currently, brand registration can be done online and offline. The registration process will be 
fast if the registered brand is different from the others. Therefore the brand process is the key to the success of brand registration. Participants are advised to study the brand registration guidelines.

\section{CONCLUSION}

In South Jakarta, MSMEs need branding training because many entrepreneurs still do not have a brand and have not registered their brand. MSMEs' knowledge of brand elements and brand registration needs to be improved. During the COVID-19 pandemic, synchronous online training was practical because trainers and participants could interact directly. Trainers need to use methods that encourage an interactive training process.

\section{ACKNOWLEDGMENT}

This activity was held in collaboration with the Department of Trade. Cooperatives and MSMEs in South Jakarta and Sahid University.

\section{REFERENCES (AND BIBLIOGRAPY AND LITERATURE WRITING)}

Akhter, S., Javed, M. K., Shah, S. Q., \& Javaid, A. (2021). Highlighting the Advantages and Disadvantages of E-Learning. PSYCHOLOGY AND EDUCATION, 58(5), 1607-1614.

Keller, K. L. (2013). Strategic Brand Management Building, Measuring, and Managing Brand Equity. In Pearson Education Limited (4e ed.). https://doi. org/10.1007/978-3-658-13561-4_3

Kohli, C., \& Labahn, D. W. (1997). OBSERVATIONS: CREATING EFFECTIVE BRAND NAMES: A STUDY OF THE NAMING PROCESS. Journal of Advertising, February, 67-76.
Undang-Undang Republik Indonesia Nomor 20 Tahun 2016 Tentang Merek dan Indikasi Geografis (The Law Number 20 Year 2016 on Trademark and Geographical Indications), 1 (2016).

Dari 64,1 Juta UMKM, Baru 10.632 yang Mengurus Merek Dagang. money.kompas.com. Retrieved July 15, 2021 from https://money.kompas.com/ $\mathrm{read} / 2020 / 07 / 17 / 161100826 /$ dari-64-1-juta-umkmbaru-10.632-yang-mengurus-merek-dagang. Penulis : Elsa Catriana

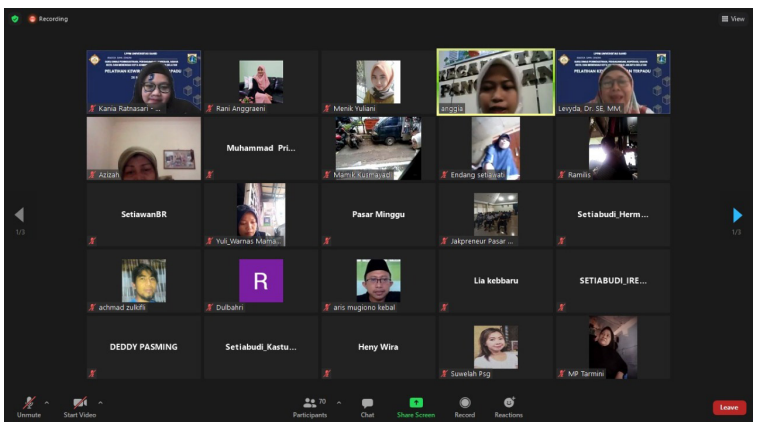

Picture 1. Webinar Participants

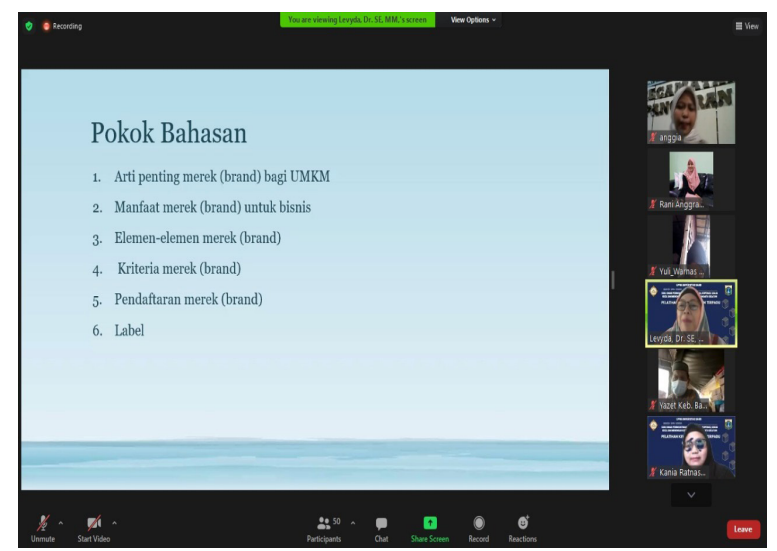

Picture 2. Presentation and Discussion 